The Influence of Nutrient Media Modification on the Morphological Parameters in Raspberry (Rubus idaeus L.) Micropropagation in the Liquid and Semi-solid Media

Utjecaj modifikacije hranjivog medija na morfološke parametre pri mikropropagaciji maline (Rubus idaeus L.) u tekućem i polučvrstom mediju

Bošnjak, D., Marković, M., Agić, D., Vinković, T., Tkalec Kojić, M., Ravnjak, B., Stanisavljević, A.

Poljoprivreda/Agriculture

ISSN: $1848-8080$ (Online)

ISSN: 1330-7142 (Print)

https://doi.org/10.18047/poljo.27.1.3

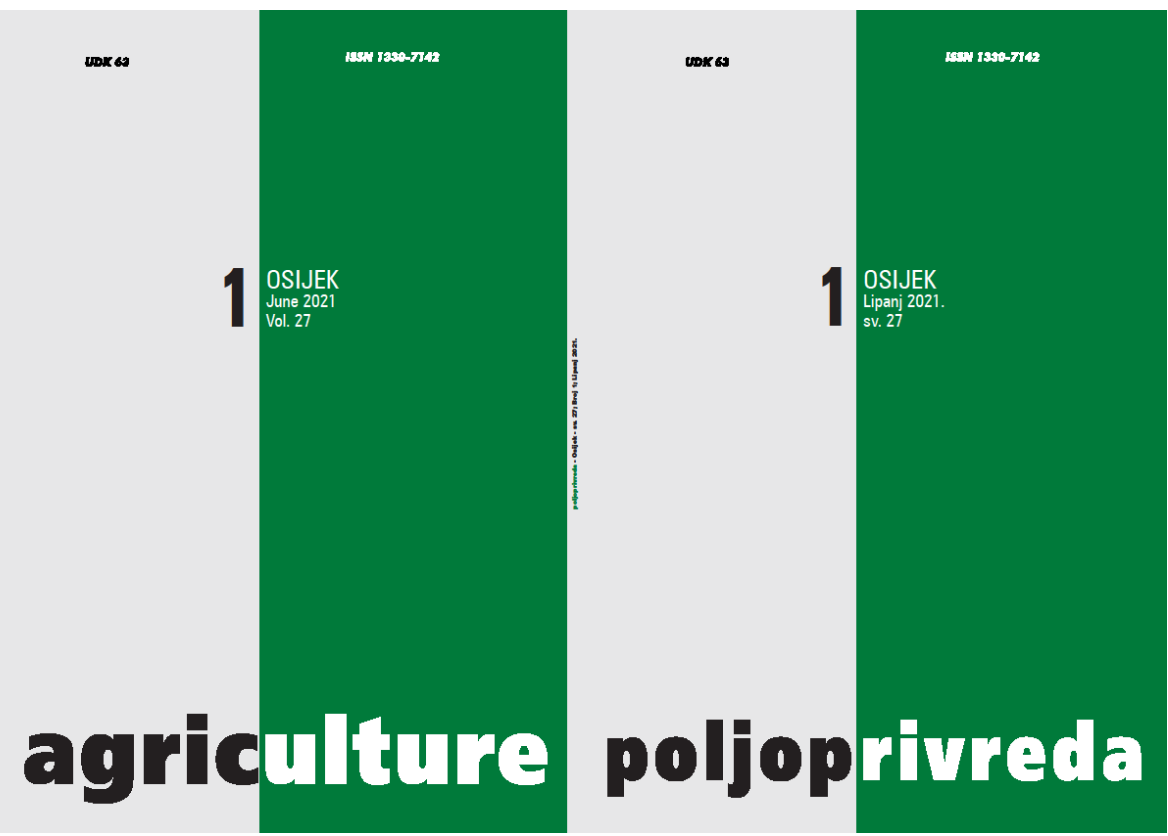

Fakultet agrobiotehničkih znanosti Osijek, Poljoprivredni institut Osijek

Faculty of Agrobiotechnical Sciences Osijek, Agricultural Institute Osijek 


\title{
THE INFLUENCE OF NUTRIENT MEDIA MODIFICATION ON THE MORPHOLOGICAL PARAMETERS IN RASPBERRY (Rubus idaeus L.) MICROPROPAGATION IN THE LIQUID AND SEMI-SOLID MEDIA
}

Bošnjak, D., Marković, M., Agić, D., Vinković, T., Tkalec Kojić, M., Ravnjak, B., Stanisavljević, A.

Original scientific paper

Izvorni znanstveni članak

\begin{abstract}
SUMMARY
Within the nursery sector, a global interest in functional fruits imposes a permanent need to improve the tissue culture technology. A modern bioreactor immersion system is currently a valid solution for the micropropagation of many cultures. At the Faculty of Agrobiotechnical Sciences Osijek (FAZOS, Croatia), a research was conducted with the aim of improving the raspberry (Rubus idaeus L., cv. HimboTop ${ }^{\circledR}$ ) micropropagation protocol. The treatments implied the modifications of the MS and DKW nutrient medium (DKW - standard; DKWm - substitution of FeEDTA with the FeEDDHA; MSm - macroelement modification, $3 \times \mathrm{CaCl}_{2}, \mathrm{MgSO}_{4}$ and $\mathrm{KH}_{2} \mathrm{PO}_{4}+\mathrm{FeEDDHA}$ ), differently depending on the aggregate condition (semi-solid and liquid SETIS ${ }^{\text {TM }}$ ). Subsequent to 15 (SETIS ${ }^{\text {TM }}$ ) and 30 cultivation days (semi-solid medium), respectively, a morphological parameter analysis and a multiplication success evaluation were commenced. In all treatments (DKW, DKWm, and MSm), the observed parameters (shoot height, number of leaves, leaf width and length) were significantly better in an interaction with the liquid medium. Comparing the models, a liquid medium (SETIS ${ }^{T M}$ ) resulted in a significantly higher explant multiplication (4.02) (a semi-solid medium - 2.74). The best reproduction quality, implying a better plant vigor with a reduced vitrification, was obtained on the MSm medium in the SETIS ${ }^{T M}$. A concentration optimization of individual mesocomponents (i.e., of the macroelements) and their chemical forms (FeEDDHA) may contribute to their improved adoption and consequently to the stress suppression due to an explant transplantation. Selecting the modern technical solutions (TIS bioreactors - SETISTM) and continuously improving the protocols, we may obtain the realistically sustainable models, suitable for a massive clonal reproduction.
\end{abstract}

Keywords: raspberry, micropropagation, TIS, medium optimization

\section{INTRODUCTION}

Raspberry (Rubus idaeus L.) represents a functional food, a "superfruit" rich in the bioactive natural substances that exert their effect on the preservation and protection of human health (Beekwilder et al., 2005; Kirina et al., 2020). Recently, a tissue-culture raspberry propagation in vitro (micropropagation) on a semi-solid medium was frequently conducted in many studies (Zawadzka and Orlikowska, 2004 and 2006; Poothong and Reed, 2014).
Micropropagation on a liquid medium is considered to be more efficient if compared to a semi-solid one because the plants produce a higher biomass and reduce a propagation time due to a better media compo-

Dejan Bošnjak, M. Eng. Agr. (dbosnjak@fazos.hr), Assoc. Prof. Monika Marković, Assist. Prof. Dejan Agić, Assoc. Prof. Tomislav Vinković, Monika Tkalec Kojić, Ph. D., Boris Ravnjak, M. Eng. Agr., Prof. Dr. Aleksandar Stanisavljević - Josip Juraj Strossmayer University of Osijek, Faculty of Agrobiotechnical Sciences Osijek, Vladimira Preloga 1, 31000 Osijek, Croatia 
nent availability, manipulation and automation are easier (representing a labor cost reduction), and there are no costs incurred by the usage of agar (Welander et al., 2014; Stanisavljević et al., 2017). Recently, a multitude of bioreactor systems deploying a liquid temporaryimmersion nutrient medium (temporary immersion bioreactors/systems, TIBs/TIS's) have been developed (Georgiev et al., 2014). Lotfi and Werbrouck (2018) have presented the SETIS ${ }^{\text {TM }}$ immersion bioreactor (Vervit, Belgium) as a very exciting new tool for a commercial micropropagation, with a special attention paid to the system setup and manipulation to avoid contamination. Bello-Bello (2019) confirmed the SETIS ${ }^{\mathrm{TM}}$ working principle and efficiency on the banana explants.

It is known that an in vitro plant multiplication coefficient depends on a genotype, nutrient medium composition, physical culture conditions, subcultivation, etc. (Tsao and Reed, 2002). The inorganic mineral components are the main constituents of a plant-tissue culture media and play a very important role in the in vitro plant growth and development (Murashige and Skoog, 1962). Raspberry micropropagation usually partakes the usage of the MS media and/or its modification (Zawadzka and Orlikowska, 2006; Poothong and Reed, 2014). One of the most important components of a nutrient medium is iron (Fe), which participates in the processes of regulation and redox transformations and is a part of the coenzyme. Its role is very important in the chlorophyll biosynthesis, and iron deficiency strongly limits the growth of plants and causes chlorosis (Guerinot, 2001). Additionally, iron alters the structure of chloroplasts and exerts an effect on the efficiency of photosynthesis. Iron is most commonly used in the chelated FeEDTA form (i.e., as the iron-ethylenediaminetetraacetic acid). The in vitro shoots of some raspberry cultivars often suffer from leaf chlorosis caused by iron deficiency (Badjakov et al., 2020).

In an in vitro suppression of raspberry chlorosis, many researchers present the positive results and methods: a double amount of FeEDTA in the MS medium (Sobczykiewicz, 1984), an $\mathrm{MgSO}_{4}$ concentration increased by $200 \%$ and a FeEDTA concentration increased by $50 \%$, and a substitution of FeEDTA with FeEDDHA - ethylenediamine di-2-hydroxy-phenylacetate-ferrite (Zawadzka and Orlikowska, 2006 and 2009). $\mathrm{Ca}, \mathrm{Mg}, \mathrm{S}, \mathrm{P}$ and $\mathrm{K}$ play an important role as the essential molecule components in plant cells (Ramage and Williams, 2002). Potassium is generally required for an osmotic balance and for the opening and closing of stomata. Magnesium and phosphorus are the cofactors in phosphorylation reactions, and magnesium is a central chlorophyll molecule. Sulfur is necessary to convert the nitrates to certain amino acids and is involved in the production of chlorophyll. Calcium is required in the cellwall synthesis in the form of calcium pectate, which is deposited in the center of lamella and plays an important mediator role in the regulation of cellular processes.
Therefore, these elements' deficiency or toxicity will cause the symptoms such as a slow growth, hyperhydricity (vitrification), and explant chlorosis (Bairu et al., 2009; Ivanova and Van Staden, 2009). The positive effects of an increase in these MS semi-solid medium's mesogroup elements by 2.5 to 3 times are reported by Poothong and Reed (2014) in the micropropagation of five raspberry cultivars. The aim of the study was to examine the influence of a nutrient medium modification on the growth and development (morphological parameters) of raspberry (Rubus idaeus L., cv. HimboTop ${ }^{\circledR}$ ) while comparing a liquid temporary immersion system bioreactor (SETIS ${ }^{\mathrm{TM}}$ ) with a standard tissue culture model on a semi-solid medium.

\section{MATERIAL AND METHODS}

The research was conducted at the Faculty of Agrobiotechnical Sciences Osijek during the years of 2019 and 2020, respectively. The experiment treatments implied a micropropagation of the HimboTop ${ }^{\circledR}$ raspberry (Rubus idaeus L.) cultivar with the modifications $(\mathrm{m})$ of the MS and DKW nutrient media, different in respect of their physical states (semi-solid and the liquid SETIS ${ }^{\mathrm{TM}}$ ). A DKW treatment (Driver and Kuniyuki, 1984) contained standard micro- and macrosalt formulations and a vitamin formulation of the same group. A DKWm treatment also contained all the microsalts, macrosalts, and vitamins of the abovementioned formulation, with an iron (FeEDTA) substitution with the chelated FeEDDHA form (118 mg/l). An MSm treatment involved a MS mesogroup's macroelement media modification (Murashige and Skoog, 1962), i.e., according to Poothong and Reed (2014), a concentration of $\mathrm{CaCl}_{2}, \mathrm{MgSO}_{4}$, and $\mathrm{KH}_{2} \mathrm{PO}_{4}$ was increased by three times, and the standard iron FeEDTA form was replaced with the FeEDDHA (118 $\mathrm{mg} / \mathrm{l})$. The other MS media components were not unaltered. All treatments contained $30 \mathrm{~g} / \mathrm{l}$ of sugar, 6.3 $\mathrm{g} / \mathrm{l}$ of agar (a semi-solid medium), $0.8 \mathrm{mg} / \mathrm{l}$ of cytokine BAP (6-benzylaminopurine) and $0.01 \mathrm{mg} / \mathrm{l}$ of auxin IBA (indole-3-butyric acid).

In all treatments, the $\mathrm{pH}$ was adjusted to 5.8 prior to autoclaving $\left(121^{\circ} \mathrm{C}, 1.1 \mathrm{bar}, 20\right.$ mins.). Each bioreactor was filled with 1 I of medium, and each jar was filled with $100 \mathrm{ml}$ of medium. Subsequent to the initiation, all treatments (i.e., jars and bioreactors) were placed in an air chamber under a 16/8 light photoperiod (3.600 lux, Voltcraft MS-200LED) and a temperature amounting to $23 \pm 0.5^{\circ} \mathrm{C}$. The SETIS ${ }^{\mathrm{TM}}$ was set to four immersion modes per day using a CPU's control unit (every 6 hrs. for 3 mins.), with a system ventilation set on every 3 hrs. for 2 mins. Each treatment on a semi-solid medium involved 25 plants in four repetitions (100 plants).

The treatments in the SETIS ${ }^{\mathrm{TM}}$ system involved 100 plants in three repetitions (300 plants). The research examined the treatment effects exerted on the following parameters $(n=25$ plants): the plants' morphological parameters in both models (shoot length, number of shoots/multiplications, number of leaves, leaf length and 
width) and the $\mathrm{pH}$ movement in the liquid medium subsequent to seven days and at the cycle end. Subsequent to the development of ideal biomass and plant growth, i.e., the end of a multiplication cycle (SETIS ${ }^{\text {TM }}$ - 15 days, a semi-solid medium - 30 days), the abovementioned parameters were measured. The collected data were analyzed using Microsoft Office Excel 2016 and SAS Enterprise Guide 7.1 (SAS Institute Inc., Cary, NC, USA, 2017) software. Concerning the statistical methods, the one- and two-factor ANOVA was used, and the differences between the mean values of the applied treatments were examined by Fisher's LSD test, with the significance level amounting to $p \leq 0.05$.

\section{RESULTS AND DISCUSSION}

On an overall experiment level (Table 1), when compared to the other treatments, a treatment with a modified MSm medium resulted in a significantly larger shoot length and in a lower number of leaves. In addition, no significant difference was observed between the examined media in respect of its influence on the leaf size (leaf length and width), which is in contrast to the results obtained by Poothong and Reed (2014). The authors state that an increase in the macronutrient mesocomponents (MSm) resulted in a better biomass production. In most of the observed morphological parameters, comparing the DKW and DKWm media individually (Table 1), no functional improvement was found as a result of the FeEDTA iron substitution with the FeEDDHA. Although it was reported that an increase in the concentration of macronutrient mesocomponents also increases the number of shoots, i.e., multiplication (Wada et al., 2013, concerning the Pyrus spp. explants and Poothong and Reed, 2015, concerning the Rubus idaeus L.), there were not significant differences between treatments in our research (Table 1).

Table 1. The effect of medium (DKW, DKWm, and MSm), model (semi-solid and SETIS ${ }^{\mathrm{TM}}$ ), and of a treatment $x$ model interaction on a morphological parameter in Rubus idaeus L., cv. HimboTop ${ }^{\circledR}$ micropropagation

Tablica 1. Utjecaj medija (DKW, DKWm i MSm) i modela (polučvrsti i SETIS ${ }^{T M}$ ) te interakcija tretman x model na morfološke parametre u mikropropagaciji Rubus idaeus L. cv. HimboTop ${ }^{\circledR}$

\begin{tabular}{|c|c|c|c|c|c|}
\hline & $\begin{array}{c}\text { Shoot length } \\
\text { Dužina izdanaka }(\mathrm{mm})\end{array}$ & $\begin{array}{c}\text { Number of shoots } \\
\text { Broj izdanaka }\end{array}$ & $\begin{array}{c}\text { Number of leaves } \\
\text { Broj listova }\end{array}$ & $\begin{array}{c}\text { Leaf length } \\
\text { Dužina listova }(\mathrm{mm})\end{array}$ & $\begin{array}{c}\text { Leaf width } \\
\text { Širina listova }(\mathrm{mm})\end{array}$ \\
\hline \multicolumn{6}{|c|}{ Treatment / Tretmani } \\
\hline DKW & $27.98 \pm 9.05 b$ & $3.18 \pm 1.24$ & $34.88 \pm 14.37 b$ & $5.93 \pm 3.04$ & $5.15 \pm 2.70$ \\
\hline DKWm & $24.28 \pm 4.84 c$ & $3.28 \pm 1.20$ & $34.63 \pm 15.33 b$ & $5.06 \pm 3.08$ & $4.55 \pm 2.75$ \\
\hline $\mathrm{MSm}$ & $34.76 \pm 7.02 \mathrm{a}$ & $3.69 \pm 2.24$ & $28.03 \pm 11.49 a$ & $5.70 \pm 4.04$ & $5.35 \pm 3.63$ \\
\hline F-test & 24.70 & 1.30 & 4.68 & 2.21 & 2.86 \\
\hline$p$ & $<.0001$ & 0.2762 & 0.0112 & 0.1139 & 0.0612 \\
\hline \multicolumn{6}{|c|}{ Model } \\
\hline $\begin{array}{l}\text { Semi-solid } \\
\text { Polučvrsti }\end{array}$ & $28.60 \pm 7.12$ & $2.74 \pm 0.86 b$ & $25.53 \pm 6.79 b$ & $2.80 \pm 1.47 \mathrm{~b}$ & $2.43 \pm 0.88 \mathrm{~b}$ \\
\hline SETIS TM & $29.41 \pm 9.46$ & $4.02 \pm 1.95 a$ & $39.48 \pm 15.95 a$ & $8.33 \pm 2.38 a$ & $7.61 \pm 2.09 a$ \\
\hline F-test & 0.43 & 21.22 & 45.24 & 251.11 & 337.00 \\
\hline$p$ & 0.5144 & $<.0001$ & $<.0001$ & $<.0001$ & $<.0001$ \\
\hline \multicolumn{6}{|c|}{ Interaction treatment $\mathrm{x}$ model / Interakcija tretman $\mathrm{x}$ model } \\
\hline F-test & 8.55 & 0.37 & 7.03 & 4.00 & 3.66 \\
\hline$p$ & 0.0003 & 0.6891 & 0.0013 & 0.0209 & 0.0289 \\
\hline
\end{tabular}

* The data present an average in all repetitions (mean \pm standard deviation). The mean values, demarcated with different letters inside the columns, indicate a statistically significant difference pursuant to Fisher's LSD test, $\mathrm{p} \leq 0.05, \mathrm{n}=25$ / Podatci su prosjek svih ponavljanja (prosječna vrijednost \pm standardna devijacija). Prosječne vrijednosti tretmana i modela (u stupcu tablice) označene različitim slovima statistički se značajno razlikuju (Fisher LSD test; $p \leq 0,05$ ), $n=25$

On the experiment level, the treatments conducted in the SETIS ${ }^{\text {TM }}$ (liquid medium) resulted in a regeneration of explants with a significantly higher number of leaves, a larger number of shoots/multiplications, and longer and wider leaves in relation to a semi-solid medium. The SETIS ${ }^{\mathrm{TM}}$ and semi-solid media resulted in the shoots having a equal length, without significant difference. Factorial analysis of variance revealed a significant interaction of treatments and models with regard to the shoot lengths $(p=0.0003)$, number of leaves $(p=0.0013)$, leaf length $(p=0.0209)$ and leaf width $(p=0.0289)$.

In the SETIS ${ }^{\mathrm{TM}}$ model in a MSm treatment, the shoot and leaf lengths and widths were significantly higher when compared to all other treatments (Fig. 1). The DKW and DKWm treatments, also in the SETIS ${ }^{\text {TM }}$ model, resulted in a significantly higher number of leaves when compared to other treatments. A reaction significance - i.e., a higher shoot length by virtue of 
an increase in the $\mathrm{MSm}\left(\mathrm{CaCl}_{2}, \mathrm{MgSO}_{4}\right.$, and $\left.\mathrm{KH}_{2} \mathrm{PO}_{4}\right)$ mesocomponents, in an interaction with the liquid medium - did not result in a synergistic increase in the number of leaves. In contrast, a significant increase in biomass (i.e., the number of leaves, with the DKW amounting to 43.95 and the $\mathrm{DKWm}$ amounting to $44.95,>$ MSm 29.55) is, we presume, a result of an increased nitrogen uptake in the form of $\mathrm{Ca}\left(\mathrm{NO}_{3}\right)_{2} \mathrm{x}$ $2 \mathrm{H}_{2} \mathrm{O}(1664.64 \mathrm{mg} / \mathrm{l})$, which is located exclusively in the DKW medium (Fig. 1).

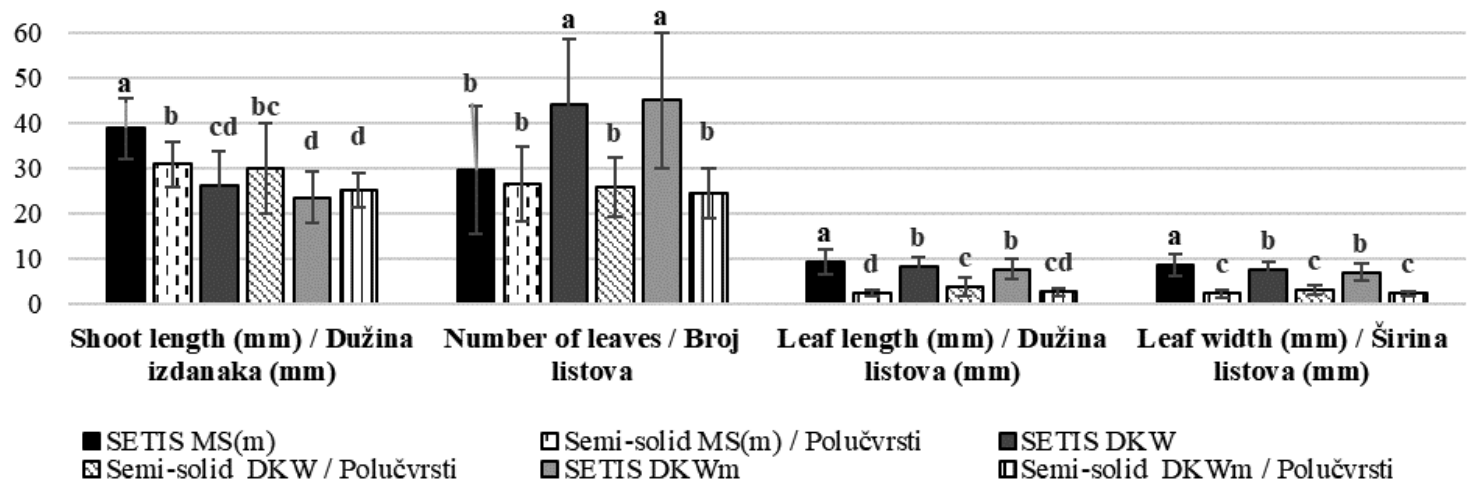

Figure 1. Interaction treatment (DKW, DKWm, MSm) $x$ model (SETIS ${ }^{\mathrm{TM}}$, semid-solid) concerning a morphological parameter in the Rubus idaeus L. cv. HimboTop ${ }^{\circledR}$ micropropagation. Different letters at the column tops indicate statistically significant difference pursuant to Fisher's LSD test $(p<0.05) \pm$ standard deviation

Slika 1. Interakcija tretman (DKW, DKWm i MSm) x model (SETISTM i polučvrsti) na morfološke parametre u mikropropagaciji Rubus idaeus L. cv. HimboTop ${ }^{\circledR}$. Stupci označeni različitim slovima statistički se značajno razlikuju (Fisher LSD test; $p \leq 0,05 ; \pm$ standardna devijacija)

The analyzed parameter results demonstrate the technological limitations of a conventional micropropagation model in a semi-solid medium. An inability to exchange the gases and a permanent solidification of the medium rapidly deplete available resources (minerals, hormones, and sugar), i.e., they extend a time required to complete a multiplication phase (30 days till a full growth and development - proliferation). We are of an opinion that the multiple enrichments of available micro- and macrosalt (MSm) levels are unjustified, except for a concentration and hormone and sugar type modification.

Table 2. A model effect (a semi-solid one and the SETIS ${ }^{\mathrm{TM}}$ model) per treatment (DKW, DKWm, and MSm) in the Rubus idaeus L. cv. HimboTop ${ }^{\circledR}$ micropropagation

Tablica 2. Utjecaj modela (polučvrsti i SETISTM) po tretmanima (DKW, DKWm i MSm) u mikropropagaciji Rubus idaeus $L$. cv. HimboTop ${ }^{\circledR}$

\begin{tabular}{|c|c|c|c|c|c|}
\hline & $\begin{array}{c}\text { Shoot length } \\
\text { Dužina izdanaka }(\mathrm{mm})\end{array}$ & $\begin{array}{c}\text { Number of shoots } \\
\text { Broj izdanaka }\end{array}$ & $\begin{array}{l}\text { Number of leaves } \\
\text { Broj listova }\end{array}$ & $\begin{array}{c}\text { Leaf length } \\
\text { Dužina listova }(\mathrm{mm})\end{array}$ & $\begin{array}{c}\text { Leaf width } \\
\text { Širina listova }(\mathrm{mm})\end{array}$ \\
\hline \multicolumn{6}{|c|}{ DKW } \\
\hline Semi-solid / Polučvrsti & $29.90 \pm 9.96$ & $2.50 \pm 0.89 b$ & $25.80 \pm 6.50 \mathrm{~b}$ & $3.60 \pm 2.06 \mathrm{~b}$ & $2.87 \pm 1.01 \mathrm{~b}$ \\
\hline SETIS ${ }^{\mathrm{TM}}$ & $26.05 \pm 7.81$ & $3.85 \pm 1.18 \mathrm{a}$ & $43.95 \pm 14.20 \mathrm{a}$ & $8.27 \pm 1.79 a$ & $7.43 \pm 1.73 a$ \\
\hline F-test & 1.85 & 16.67 & 26.33 & 58.44 & 103.48 \\
\hline$p$ & 0.1817 & 0.0002 & $<.0001$ & $<.0001$ & $<.0001$ \\
\hline \multicolumn{6}{|c|}{ DKWm } \\
\hline Semi-solid / Polučvrsti & $25.10 \pm 3.75$ & $2.80 \pm 0.62 b$ & $24.30 \pm 5.45 b$ & $2.55 \pm 0.94 b$ & $2.19 \pm 0.61 b$ \\
\hline SETIS ${ }^{\text {TM }}$ & $23.45 \pm 5.70$ & $3.75 \pm 1.45 a$ & $44.95 \pm 15.11 \mathrm{a}$ & $7.58 \pm 2.31 \mathrm{a}$ & $6.92 \pm 1.86 a$ \\
\hline F-test & 1.17 & 7.30 & 33.06 & 80.95 & 117.13 \\
\hline$p$ & 0.2864 & 0.0102 & $<.0001$ & $<.0001$ & $<.0001$ \\
\hline \multicolumn{6}{|c|}{$\mathrm{MSm}$} \\
\hline Semi-solid / Polučvrsti & $30.80 \pm 4.93 b$ & $2.93 \pm 1.02 b$ & $26.50 \pm 8.27$ & $2.24 \pm 0.72 b$ & $2.22 \pm 0.82 \mathrm{~b}$ \\
\hline SETIS ${ }^{\mathrm{TM}}$ & $38.73 \pm 6.63 a$ & $4.45 \pm 2.84 a$ & $29.55 \pm 14.06$ & $9.16 \pm 2.79 a$ & $8.48 \pm 2.42 a$ \\
\hline F-test & 18.42 & 5.08 & 0.70 & 115.58 & 120.37 \\
\hline$p$ & 0.0001 & 0.0300 & 0.4083 & $<.0001$ & $<.0001$ \\
\hline
\end{tabular}

* The data for a semi-solid model are an average of four repetitions and of three repetitions for the SETISTM model (mean \pm standard deviation). The mean values demarcated with different letters inside the columns, indicate a statistically significant difference pursuant to Fisher's LSD test, $\mathrm{p} \leq 0.05, \mathrm{n}=25 /$ Podatci za polučvrsti su prosjek 4 ponavljanja i SETIS ${ }^{T M} 3$ ponavljanja (prosječna vrijednost \pm standardna devijacija). Prosječne vrijednosti modela po tretmanima (u stupcu tablice) označene različitim slovima statistički se značajno razlikuju (Fisher LSD test; $p \leq 0,05$ ), $n=25$ 
In all treatments (DKW, DKWm, and the MSm) in the SETIS ${ }^{\mathrm{TM}}$ model, the explants have developed significantly larger leaves (leaf length and width) when compared to a semi-solid medium (Fig. 1, Table 2). The number of leaves in the control DKW and DKWm treatments and the shoot lengths in the MSm treatment were also significantly higher on the explants cultivated in the SETIS TM model (Table 2). To sum up, all explants in the SETIS ${ }^{T M}$ model have developed a higher biomass and more favorable morphological characteristics in just 15 days (Table 2). This indicates that the conditions in the SETIS ${ }^{\mathrm{TM}}$ model (a better dispersion and distribution of nutrients and aeration - gas exchange and moisture control) favored a higher macro- and microelements adoption efficiency. Although Zawadzka and Orlikowska (2004 and 2009) reported a positive effect of the FeEDDHA chelate (MSm medium) exerted on the biomass production, this was not confirmed by our research. The visual plant assessment results at the cycle end (a more pronounced vigor and an intense chlorophyll color - leaf, Fig. 2), suggests, however, that a future use of this form of iron in temporary immersion systems is justified.
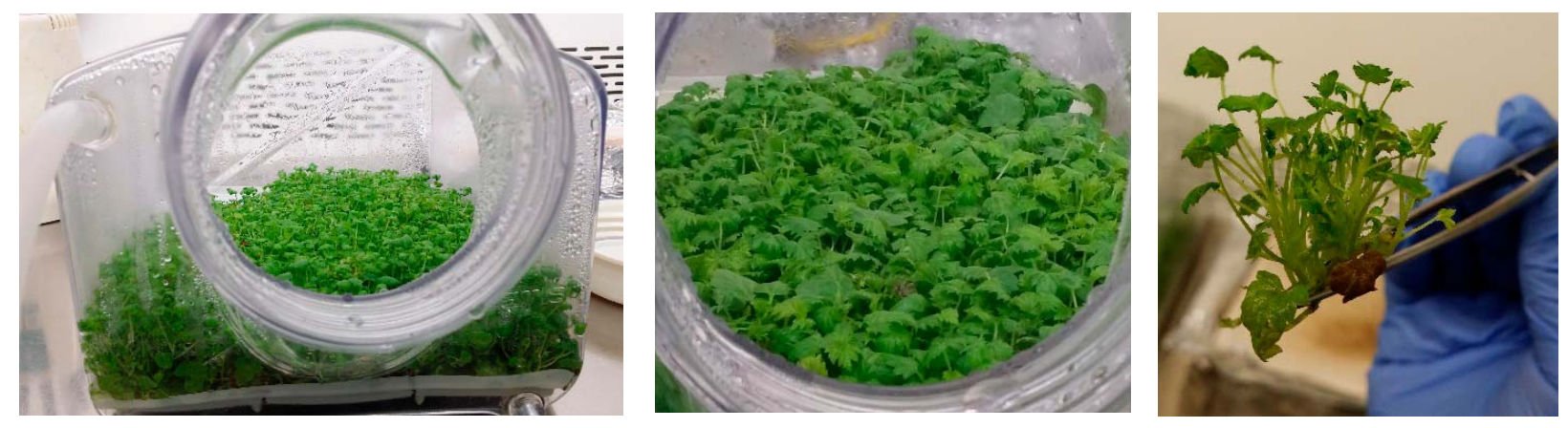

a. MSm SETIS ${ }^{\mathrm{TM}}$ - 15 days
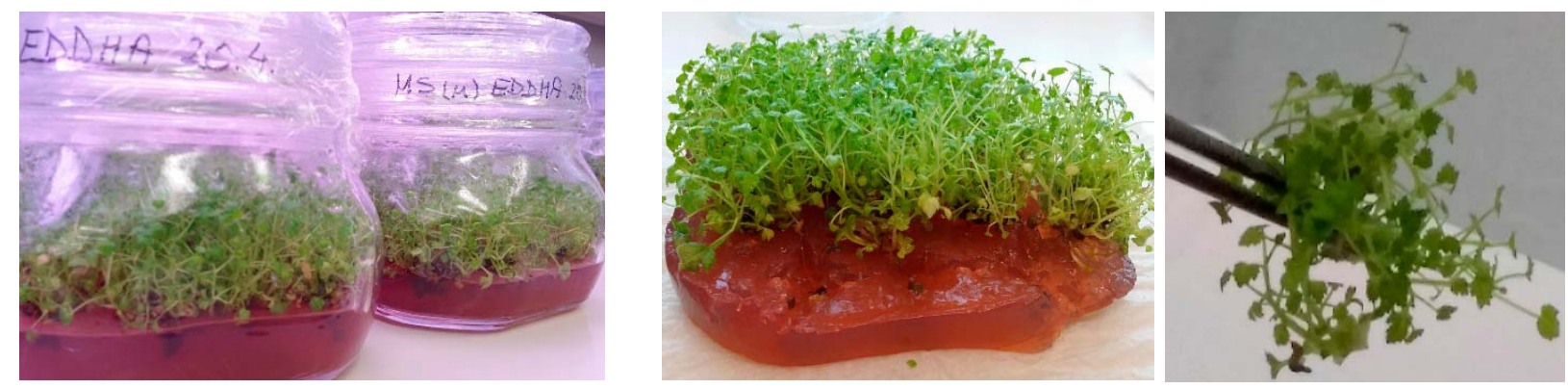

b. MSm Semi-solid / Polučvrsti - $\mathbf{3 0}$ days

Figure 2. The differences between the models (a. SETIS ${ }^{\mathrm{TM}}$ model and $\mathrm{b}$. Semi-solid model) in biomass production in a MSm treatment

Slika 2. Razlike između modela (a. SETIS ${ }^{T M}$ i b. polučvrsti) u produkciji biomase na tretmanu MSm

Chakrabarty et al. (2007) reported that the plants cultivated in the TIS system have a higher photosynthetic activity, especially a photosystem II activity. According to Shibli et al. (2002), a high stability of this iron chelate allows for a permanence and maintenance of constant initial ionic balance in the medium. The efficiency of this form has been confirmed in other cultures: Vaccinium corymbosum L. (Clapa et al., 2008), Juglans regia L. (Licea-Moreno et al., 2015), and Corylus avellana L. (Silvestri et al., 2020). The efficiency of SETIS ${ }^{\text {TM }}$ temporary immersion system in the formation of a greater number of shoots (multiplication) in raspberries was proven in all research treatments. The greatest number of shoots/multiplications in the SETIS ${ }^{\mathrm{TM}}$ model was observed in a MSm treatment (Table 2). Debnath (2011) also confirmed a high proliferation rate on three raspberry cultivars in the RITA ${ }^{\circledR}$ immersion bioreactor.
Regardless of a system modification (bioreactor), a liquid medium as a nutrient carrier confirms the improvement of multiplication quality (Zhu et al., 2005).

One of the crucial problems manifested in a tissue culture while using a liquid medium is the development of an excessive hyperhydricity (vitrification) of a newly developed tissue. Etienne and Berthouly (2002) cited that aeration and intermittent immersion are most frequently the keys to success of a TIS system. In the conducted research, an immersion four times per day (every 6 hrs.), lasting for 3 mins., with a system ventilation every $3 \mathrm{hrs}$. (lasting for 2 mins.), resulted in an ideal biomass production in just 15 days. A visual plant analysis during and subsequent to the end of a multiplication phase in all treatments in a semi-solid medium did not demonstrate the occurrence of an explant vitrification. Shibli et al. (1997) cited that the FeEDDHA 
alleviates the incidence of hyperhydricity, which can be partially confirmed by our research results. A vitrification in the SETIS ${ }^{\mathrm{TM}}$ system, i.e., in the MSm and DKWm treatments, resulted, namely, in the acceptable $20 \%$ of the vitrified explants and in $30-40 \%$ of them in case of a DKW treatment. We presume that the conditions were optimal (bioreactor) and have increased the concentration of mesocomponents (MSm) in combination with an
FeEDDHA form, resulting in an optimal growth (15 days, Fig. 2, first picture) and, accordingly, in an appropriate photosynthetic activity. In this way, a possibly harmful free-water bioaccumulation in the tissue (hyperhydration) is compensated by a progressive explant growth. It is to be expected that the present vitrification can be further reduced by optimizing the SETIS ${ }^{\mathrm{TM}}$ system through a number of immersions and vents.

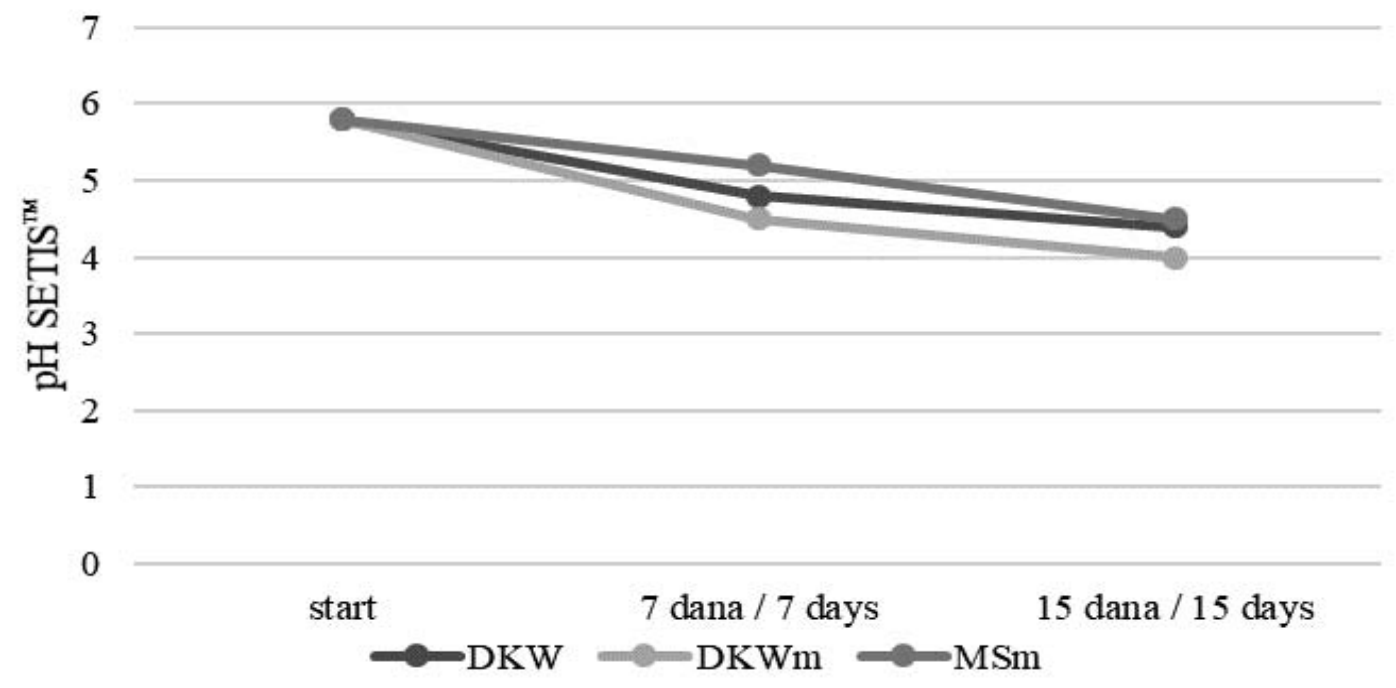

Figure 3. A pH dynamic - SETIS ${ }^{\mathrm{TM}}$ during 15 days of cultivation

Slika 3. Dinamika $\mathrm{pH}$ - SETIS ${ }^{T M}$ tijekom 15 dana kultivacije

One of the challenges in a liquid-medium usage technology is a stability of the nutrient medium's $\mathrm{pH}$ value, which is further emphasized by a selected culture and/or cultivar. The medium $\mathrm{pH}$ value was adjusted to 5.8 prior to autoclaving. Subsequent to seven days, the $\mathrm{pH}$ value decreased in all treatments (5.2 to 4.5 ), and subsequent to 15 days, a very unfavorable value was measured, ranging from 4.5 to 4.0 (Fig. 3). A plant material adopts certain medium-derived mineral components for its growth, which reduces the $\mathrm{pH}$ value and conductivity. A decrease in the medium's $\mathrm{pH}$ value in a TIS system is reported by Chakrabarty et al. (2007) and Persson (2012). The problem of an endogenous pathogen development (contamination) on the pear explants in a SETIS ${ }^{\mathrm{TM}}$ system is presented by Lofti et al. (2020), prevented by adding the PPM ${ }^{\mathrm{TM}}$ biocides to the used medium. One of the possible solutions to a suppression of a decrease in the liquid medium's $\mathrm{pH}$ value is a $\mathrm{pH}$ value correction during the cycle or a complete replacement of the medium with a fresh one (which raises a question of profitability).

\section{CONCLUSION}

The modern designs of temporary immersion systems have no alternative in automating a massive clonal reproduction of the plant material. By virtue of a significant interaction with the SETIS ${ }^{\mathrm{TM}}$ model (liquid medium), all applied treatments (DKW, DKWm, and $\mathrm{MSm}$ ) resulted in an effective abbreviation of this cultivation phase ( 15 days), i.e., in a significant increase in multiplication (4.02 \pm 1.95$)$, total biomass, and raspberry explant vigor (Rubus ideaeus L., cv. HimboTop ${ }^{\circledR}$ ). The best reproduction quality (shoot lengths, multiplication, leaf lengths and widths, plant vigor, chlorophyll and vitrification), however, was obtained in the MSm (liquid medium). The obtained results indicate that we may further improve a stress suppression and explant acclimatization in the TIB systems by modifying the nutrient medium and optimizing the mesocomponent concentrations and their chemical forms (FeEDDHA). The activation velocity of an autonomous photoautotrophic metabolism is a key to the production of a high-quality biomass and to a production cycle abbreviation in the temporary immersion bioreactor systems.

\section{ACKNOWLEDGEMENT}

This research was funded by Josip Juraj Strossmayer University of Osijek as a part of the UNIOS-ZUP 2018-34 Scientific Research Project, entitled Contemporary Production of Fruit Planting Material by in vitro Tissue Culture (Suvremena proizvodnja voćnog sadnog materijala in vitro kulturom tkiva). 


\section{REFERENCES}

1. Badjakov, I., Georgiev, V., Georgieva, M., Dincheva, I., Vrancheva, R., Ivanov, I., ... \& Pavlov, A. (2021). Bioreactor technology for in vitro berry plant cultivation. Plant Cell and Tissue Differentiation and Secondary Metabolites: Fundamentals and Applications, 383-431. https://doi.org/10.1007/978-3-030-11253-0_18-1

2. Bairu, M. W., Stirk, W. A., \& Van Staden, J. (2009). Factors contributing to in vitro shoot-tip necrosis and their physiological interactions. Plant Cell, Tissue and Organ Culture (PCTOC), 98(3), 239-248.

https://doi.org/10.1007/s11240-009-9560-8

3. Beekwilder, J., Jonker, H., Meesters, P., Hall, R. D., van der Meer, I. M., \& Ric de Vos, C. H. (2005). Antioxidants in raspberry: on-line analysis links antioxidant activity to a diversity of individual metabolites. Journal of Agricultural and Food Chemistry, 53(9), 3313-3320. https://doi.org/10.1021/jf047880b

4. Bello-Bello, J. J., Cruz-Cruz, C. A., \& Pérez-Guerra, J. C. (2019). A new temporary immersion system for commercial micropropagation of banana (Musa AAA cv. Grand Naine). In Vitro Cellular \& Developmental BiologyPlant, 55(3), 313-320. https://doi.org/10.1007/s11627-019-09973-7

5. Chakrabarty, D., Dewir, Y. H., Hahn, E. J., Datta, S. K., \& Paek, K. Y. (2007). The dynamics of nutrient utilization and growth of apple root stock 'M9 EMLA'in temporary versus continuous immersion bioreactors. Plant Growth Regulation, 51(1), 11-19. https://doi.org/10.1007/s10725-006-9115-5

6. Clapa, D., Fira, A., \& Rusu, T. (2008). The use of Isubgol and Sequestrene 138 for the in vitro propagation of the highbush blueberry (Vaccinium corymbosum L.). Journal of Food Agriculture and Environment, 6(1), 145.

7. Debnath, S. (2011). Bioreactors and molecular analysis in berry crop micropropagation-A review. Canadian Journal of Plant Science, 91(1), 147-157. https://doi.org/10.4141/CJPS10131

8. Driver, J. A., \& Kuniyuki, A. H. (1984). In vitro propagation of Paradox walnut rootstock. HortScience, 19(4), 507-509.

9. Etienne, H., \& Berthouly, M. (2002). Temporary immersion systems in plant micropropagation. Plant Cell, Tissue and Organ Culture, 69(3), 215-231. https://doi.org/10.1023/A:1015668610465

10. Georgiev, V., Schumann, A., Pavlov, A., \& Bley, T. (2014). Temporary immersion systems in plant biotechnology. Engineering in life sciences, 14(6), 607-621. https://doi.org/10.1002/elsc.201300166

11. Guerinot, M. L. (2001). Improving rice yields-ironing out the details. Nature Biotechnology, 19(5), 417-418. https://doi.org/10.1038/88067

12. Ivanova, M., \& Van Staden, J. (2009). Nitrogen source, concentration, and $\mathrm{NH}_{4}{ }^{+}: \mathrm{NO}_{3}^{-}$ratio influence shoot regeneration and hyperhydricity in tissue cultured Aloe polyphylla. Plant Cell, Tissue and Organ Culture (PCTOC), 99(2), 167-174.

https://doi.org/10.1007/s11240-009-9589-8
13. Kirina, I. B., Belosokhov, F. G., Titova, L. V., Suraykina, I. A., \& Pulpitow, V. F. (2020, August). Biochemical assessment of berry crops as a source of production of functional food products. In IOP Conference Series: Earth and Environmental Science (Vol. 548, No. 8, p. 082068). IOP Publishing. https://doi.org/10.1088/1755-1315/548/8/082068

14. Licea-Moreno, R. J., Contreras, A., Morales, A. V., Urban, I., Daquinta, M., \& Gomez, L. (2015). Improved walnut mass micropropagation through the combined use of phloroglucinol and FeEDDHA. Plant Cell, Tissue and Organ Culture (PCTOC), 123(1), 143-154. https://doi.org/10.1007/s11240-015-0822-3

15. Lotfi, M., \& Werbrouck, S. P. O. (2018, August). SETIS ${ }^{\mathrm{TM}}$, a novel variant within the temporary immersion bioreactors. In XXX International Horticultural Congress IHC2018: II International Symposium on Micropropagation and In Vitro Techniques 1285 (pp. 253-258).

https://doi.org/10.17660/ActaHortic.2020.1285.37

16. Lotfi, M., Bayoudh, C., Werbrouck, S., \& Mars, M. (2020). Effects of meta-topolin derivatives and temporary immersion on hyperhydricity and in vitro shoot proliferation in Pyrus communis. Plant Cell, Tissue and Organ Culture (PCTOC), 1-7. https://doi.org/10.1007/s11240-020-01935-x

17. Murashige, T., \& Skoog, F. (1962). A revised medium for rapid growth and bio assays with tobacco tissue cultures. Physiologia plantarum, 15(3), 473-497.

18. Persson, J. (2012). Evaluation of a new type of temporary immersion system (TIS) bioreactors for plant micropropagation. Degree Project in the Horticultural Science Program. Swedish University of Agricultural Sciences

19. Poothong, S., \& Reed, B. M. (2014). Modeling the effects of mineral nutrition for improving growth and development of micropropagated red raspberries. Scientia Horticulturae, 165, 132-141. https://doi.org/10.1016/j.scienta.2013.10.040

20. Poothong, S., \& Reed, B. M. (2015). Increased CaCl 2, MgSO 4, and KH 2 PO 4 improve the growth of micropropagated red raspberries. In Vitro Cellular \& Developmental Biology-Plant, 51(6), 648-658. https://doi.org/10.1007/s11627-015-9720-y

21. Ramage, C. M., \& Williams, R. R. (2002). Mineral nutrition and plant morphogenesis. In Vitro Cellular \& Developmental Biology-Plant, 38(2), 116-124. https://doi.org/10.1079/IVP2001269

22. Shibli, R. A., Smith, M. A. L., \& Nasi, R. (1997). Iron source and cytokinin mitigate the incidence of chlorosis and hyperhydration in vitro. Journal of plant nutrition, 20(6), 773-781. https://doi.org/10.1080/01904169709365293

23. Shibli, R. A., Mohammad, M. J., \& Ajlouni, Z. I. (2002). Growth and micronutrient acquisition of in vitro grown bitter almond and sour orange in response to iron concentration from different iron chelates. Journal of Plant Nutrition, 25(7), 1599-1606. https://doi.org/10.1081/PLN-120005410

24. Silvestri, C., Rugini, E., \& Cristofori, V. (2020). The effect of CuSO4 for establishing in vitro culture, and the role 
nitrogen and iron sources in in vitro multiplication of Corylus avellana L. cv. Tonda Gentile Romana. Plant Biosystems-An International Journal Dealing with all Aspects of Plant Biology, 154(1), 17-23.

https://doi.org/10.1080/11263504.2018.1549610

25. Sobczykiewicz, D. (1984). Mass production of raspberry plantlet through micropropagation and rooting them directly in sand-peat mixture.

26. Stanisavljević, A., Bošnjak, D., Štolfa, I., Špoljarević, M., Popović, B., Lisjak, M., \& Teklić, T. (2017). Suvremena klonska reprodukcija biljaka. Zbornik sažetaka, 52. hrvatski i 12. međunarodni simpozij agronoma. Urednici: Sonja Vila i Zvonko Antunović, Poljoprivredni fakultet Sveučilišta Josipa Jurja Strossmayera u Osijeku. Dubrovnik, Republika Hrvatska, 12.-17.02.2017., 265266.

27. Tsao, C. W. V., \& Reed, B. M. (2002). Gelling agents, silver nitrate and sequestrene iron influence adventitious shoot and callus formation from Rubus leaves. In Vitro Cellular \& Developmental Biology-Plant, 38(1), 29-32. https://doi.org/10.1079/IVP2001245

28. Wada, S., Niedz, R. P., DeNoma, J., \& Reed, B. M. (2013). Mesos components (CaCl 2, MgSO 4, KH 2 PO 4) are critical for improving pear micropropagation. In Vitro Cellular \& Developmental Biology-Plant, 49(3), 356-365. https://doi.org/10.1007/s11627-013-9508-x
29. Welander, M., Persson, J., Asp, H., \& Zhu, L. H. (2014). Evaluation of a new vessel system based on temporary immersion system for micropropagation. Scientia Horticulturae, 179, 227-232.

https://doi.org/10.1016/j.scienta.2014.09.035

30. Zawadzka, M., \& Orlikowska, T. (2004, September). Increase in the quality of raspberry cultures under the influence of FeEDDHA. In V International Symposium on In Vitro Culture and Horticultural Breeding 725 (pp. 161164). https://doi.org/10.17660/ActaHortic.2006.725.16

31. Zawadzka, M., \& Orlikowska, T. (2006). The influence of FeEDDHA in red raspberry cultures during shoot multiplication and adventitious regeneration from leaf explants. Plant cell, tissue and organ culture, 85(2), 145. https://doi.org/10.1007/s11240-005-9063-1

32. Zawadzka, M., \& Orlikowska, T. (2009). Influence of FeEDDHA on in vitro rooting and acclimatisation of red raspberry (Rubus idaeus L.) in peat and vermiculite. The Journal of Horticultural Science and Biotechnology, 84(6), 599-603.

https://doi.org/10.1080/14620316.2009.11512572

33. Zhu, L. H., Li, X. Y., \& Welander, M. (2005). Optimisation of growing conditions for the apple rootstock M26 grown in RITA containers using temporary immersion principle. In Liquid Culture Systems for in vitro Plant Propagation (pp. 253-261). Springer, Dordrecht. https://doi.org/10.1007/1-4020-3200-5_17

\section{UTJECAJ MODIFIKACIJE HRANJIVOG MEDIJA NA MORFOLOŠKE PARAMETRE PRI MIKROPROPAGACIJI MALINE (Rubus idaeus L.) U TEKUĆEM I POLUČVRSTOM MEDIJU}

\section{SAŽETAK}

Globalni interes za funkcionalnim voćem u rasadničarskom sektoru nameće permanentnu potrebu usavršavanja tehnologije kulture tkiva. Suvremeni imerzni sustav bioreaktora trenutno predstavlja validno rješenje za mikropropagaciju brojnih kultura. Pri Fakultetu agrobiotehničkih znanosti Osijek (FAZOS, Hrvatska) provedeno je istraživanje s ciljem usavršavanja protokola za mikropropagaciju maline (Rubus idaeus L.) kultivar HimboTop ${ }^{\circledR}$. Tretmani su uključivali modifikacije hranjivog medija Murashige i Skoog te Driver i Kuniyuki (DKW - standard; DKWm - supstitucija FeEDTA sa FeEDDHA; MSm - modifikacija makro elemenata 3 × CaCl ${ }_{2}, \mathrm{MgSO}_{4}$ i $\mathrm{KH}_{2} \mathrm{PO}_{4}+$ FeEDDHA), različitih obzirom na agregatno stanje (polučvrsti i tekući SETIS ${ }^{T M}$ ). Nakon 15 dana (SETIS ${ }^{T M}$ ) i 30 dana (polučvrsti medij) kultivacije izvršena je analiza morfoloških parametara te evaluacija uspješnosti multiplikacije. Na svim tretmanima (DKW, DKWm, MSm) promatrani parametri (dužina izdanka, broj izdanaka, broj listova, širina lista, dužina lista) bili su značajno bolji u interakciji sa tekućim medijem. Usporedbom modela, tekući medij (SETISTM) rezultirao je značajno većom multiplikacijom $(4,02)$ eksplantata u odnosu na polučvrsti medij $(2,74)$. Najbolja kvaliteta reprodukcije, uključujući bolji vigor biljke uz smanjenu vitrifikaciju, postignuta je na MSm mediju u SETIS $^{T M}$. Optimizacija koncentracije pojedinih mezokomponenti makro elemenata i njihovih kemijskih oblika može doprinijeti poboljšanom usvajanju istih te posljedično prevladavanju stresa uslijed transplantacije eksplantata. Odabirom suvremenih tehničkih rješenja (TIS bioreaktori - SETIS ${ }^{T M}$ ) i kontinuiranim usavršavanjem protokola moguće je dobiti realno održive modele pogodne za masovnu klonsku reprodukciju.

Ključne riječi: malina, mikropropagacija, TIS, optimizacija medija

(Received on October 20, 2020; accepted on February 1, 2021 - Primljeno 20. listopada 2020.; prihvaćeno 1. veljače 2021.) 